\title{
Five Principles for Vertical Merger Enforcement Policy
}

Jonathan B. Baker

American University Washington College of Law, jbaker@wcl.american.edu

Nancy L. Rose

Massachusetts Institute of Technology, Department of Economics, nrose@mit.edu

Steven C. Salop

Georgetown University Law Center, salop@law.georgetown.edu

Fiona Scott Morton

Yale School of Management, fiona.scottmorton@yale.edu

For inquiries, please contact Jonathan B. Baker jbaker@wcl.american.edu.

This paper can be downloaded free of charge from:

https://scholarship.law.georgetown.edu/facpub/2148

https://ssrn.com/abstract=3351391

Antitrust, Vol. 33, No. 3, Summer 2019.

This open-access article is brought to you by the Georgetown Law Library. Posted with permission of the author. Follow this and additional works at: https://scholarship.law.georgetown.edu/facpub

Part of the Antitrust and Trade Regulation Commons, and the Law and Economics Commons 


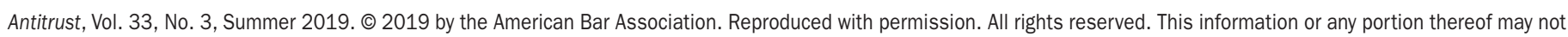

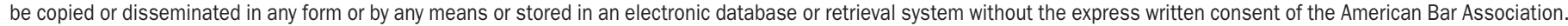

\section{Five Principles for Vertical Merger Enforcement Policy}

BY JONATHAN B. BAKER, NANCY L. ROSE, STEVEN C. SALOP, AND FIONA SCOTT MORTON

\section{V}

ERTICAL MERGERS HAVE BECOME increasingly prominent and controversial in antitrust policy-making. There seems to be consensus that the Department of Justice's 1984 Vertical Merger Guidelines, ${ }^{1}$ now 35 years old, reflect neither modern theoretical and empirical economic analysis nor current agency enforcement policy. ${ }^{2}$ There is little dispute that antitrust enforcement should be based on rigorous economic analysis. ${ }^{3}$ However, widely divergent views of preferred enforcement policies were expressed by the Federal Trade Commission Commissioners when resolving Staples's acquisition of Essendant ${ }^{4}$ and Fresenius's acquisition of NxStage, ${ }^{5}$ by Commissioner Wilson in a recent speech, ${ }^{6}$ by the various amicus briefs filed in connection with the appeal of the Justice Department's unsuccessful challenge to AT\&T's acquisition of Time Warner, ${ }^{7}$ by Assistant Attorney General Makan Delrahim, ${ }^{8}$ and by the participants at the FTC's competition policy hearing on vertical mergers. ${ }^{9}$ This broad range of views suggests the difficulty that the FTC Commissioners will face in reaching consensus on vertical mergers in any potential FTC hearings report and the problem that the two enforcement agencies will face in formulating new vertical merger guidelines. It also creates difficulties for practitioners when counseling clients or advocating in favor of, or in opposition to, proposed vertical transactions.

The D.C. Circuit's decision in United States v. AT\&T offered some guidance but did not suggest that courts should apply different legal standards to vertical mergers than to horizontal mergers. ${ }^{10}$ It observed that under Section 7 of the

Jonathan Baker is Research Professor of Law, American University Washington College of Law, and was Chief Economist, FCC (2009-2011), and Director, FTC Bureau of Economics (1995-1998)); Nancy Rose is Charles P. Kindleberger Professor of Applied Economics and Department Head, Massachusetts Institute of Technology, and was Deputy Assistant Attorney General for Economic Analysis, U.S. Department of Justice (2014-2016); Steven Salop is Professor of Economics and Law, Georgetown University Law Center; and Fiona Scott Morton is Theodore Nierenberg Professor of Economics at the Yale School of Management and was Deputy Assistant Attorney General for Economic Analysis, U.S. Department of Justice (2011-2012)). The authors thank Jonathan Jacobson and Gene Kimmelman for helpful comments, and Tomasz Mielniczuk for research assistance.
Clayton Act, "the government must show that the proposed merger is likely to substantially lessen competition, which encompasses a concept of 'reasonable probability" and accepted that the modern burden-shifting approach to evaluating merger challenges, developed in horizontal merger cases, applied to all cases brought under Section $7 .{ }^{11}$ As a result, the court left substantial gaps that the agencies and the courts will need to fill.

To assist the enforcement agencies in navigating these choppy waters, we have briefly set forth our views on critical economic analysis and process issues regarding vertical merger enforcement policy. In doing so, we assume that the agencies will base their enforcement on the burden-shifting analysis of mergers set forth by the D.C. Circuit in AT\& $T$, Baker Hughes, and Heinz (without invoking the Philadelphia National Bank $k^{12}$ horizontal merger structural presumption). A similar burden-shifting framework is applied to analyze claims brought under both Section 1 and Section 2 of the Sherman Act.

Based on our review of the economic literature on vertical integration and our experience in analyzing vertical mergers, we recommend that the agencies adopt the following five principles to guide vertical merger enforcement:

- Consider and investigate the full range of potential anticompetitive harms.

- Decline to presume that vertical mergers benefit competition in the oligopoly markets that typically prompt agency review, nor set a higher evidentiary standard based on such a presumption.

- Evaluate claimed efficiencies as carefully and critically as they evaluate those resulting from horizontal mergers, including requiring the merging parties to show that the efficiencies are verifiable, merger-specific, and sufficient to reverse the potential anticompetitive effects.

- Decline to adopt a safe harbor for vertical mergers, even if rebuttable, except perhaps when both firms compete in unconcentrated markets.

- Consider adopting rebuttable presumptions that a vertical merger harms competition when certain factual predicates (as indicated below) are satisfied.

Vertical mergers raise a number of other important policy questions that we do not discuss here, though one of us has addressed those issues extensively elsewhere. ${ }^{13}$ 


\section{Approaches to Vertical Merger Enforcement}

We next explain the rationale for these principles in more detail. Our overall concern is to reduce false negatives (including under-deterrence), while keeping false positives (including over-deterrence) low. Our analysis focuses on oligopoly markets where vertical mergers are most likely to raise concerns. We note that these may include digital marketsmarkets for services produced and consumed online- which are increasing in significance in the economy with the growth of information technology. In such markets, production economies of scale and network effects can create oligopoly structures and entry barriers, leading to the exercise of market power. That possibility raises the competitive concerns from vertical mergers.

Consider and Investigate the Full Range of Potential Competitive Harms. Enforcers should evaluate the full range of potential competitive harms when investigating vertical mergers. These harms can lead to higher prices, as well as reduced quality and innovation. ${ }^{14}$ We encourage the agencies to commit themselves to investigating all such harms. The agencies should also evaluate the full range of potential competitive benefits too, but this proposition is widely accepted.

Economic analysis-both economic theory ${ }^{15}$ and empirical studies ${ }^{16}$ — and merger enforcement ${ }^{17}$ have identified a number of ways by which vertical mergers can harm competition. Such harms include input foreclosure or customer foreclosure, and the creation of two-level entry barriers. "Foreclosure" is broadly defined. For example, input foreclosure includes price increases, cost increases, and other disadvantages placed on downstream rivals, not just total denial of the relevant input. ${ }^{18}$ We also note that "input foreclosure" would describe foreclosure after a manufacturer acquires a distributor, because the distribution services provided by a distributor are an input into the sale of the product. ${ }^{19}$ Competitive harms from foreclosure can occur from the merged firm exercising its increased bargaining leverage to raise rivals' costs or reduce rivals' access to the market. ${ }^{20}$ Vertical mergers also can facilitate coordination by eliminating a disruptive or "maverick" competitor at one vertical level, or through information exchange. ${ }^{21}$ Vertical mergers also can eliminate potential competition between the merging parties. In addition, regulated firms can use vertical integration to evade rate regulation. These competitive harms normally occur when at least one of the markets has an oligopoly structure. They can lead to higher prices, lower output, quality reductions, and reduced investment and innovation..$^{22}$

Economic analysis and merger enforcement also have identified a number of ways by which vertical mergers can lead to efficiency benefits that can increase competition. ${ }^{23}$ These benefits can include lower costs or higher quality products resulting from better integration in design or production, which can be achieved by economies of scope or better communication between the parties. By aligning incentives and preventing ex post holdup, investment and innovation incen- tives also might increase. Efficiency benefits also can include elimination of double marginalization (EDM) when the merged company sets the internal transfer price and the downstream price with a focus on joint profits instead of simply the profits of the separate businesses. ${ }^{24}$ These competitive benefits can mitigate or prevent competitive harms if they are sufficient in magnitude.

Do Not Presume that Mergers in Oligopoly Markets Benefit Competition. Some commentators have proposed that antitrust enforcement treat vertical mergers more permissively than horizontal mergers, even in concentrated markets. ${ }^{25}$ Doing so would be tantamount to presuming that vertical mergers benefit competition regardless of market structure. However, such a presumption is not warranted for vertical mergers in the oligopoly markets that typically prompt enforcement agency review. Neither economic theory nor empirical evidence supports it. Moreover, the adoption of such a presumption would permit anticompetitive vertical mergers, which then would empirically invalidate the presumption. At best, one might say that vertical mergers are unlikely to harm competition if both markets are unconcentrated. However, anticompetitive effects are possible when one market is unconcentrated, or even when both are, for reasons discussed later.

1. ECONOMic Theory. The argument that vertical merger enforcement should be very light-handed has two parts. The first is the view that vertical mergers are somehow inherently less likely to harm competition than horizontal mergers because the latter result in the loss of a horizontal rival, which tends to lead to price increases. ${ }^{26}$ For example, Robert Bork argued that vertical mergers merely rearrange buyer/ seller relationships, and he criticized an FTC case with his famous remark that the FTC should have hosted an "industry social mixer" instead of challenging the merger. ${ }^{27}$ But the claim that vertical mergers are inherently unlikely to raise horizontal concerns fails to recognize that all theories of harm from vertical mergers posit a horizontal interaction that is the ultimate source of harm. Vertical mergers create an inherent exclusionary incentive as well as the potential for coordinated effects similar to those that occur in horizontal mergers. ${ }^{28}$

The inherent exclusionary incentive can be explained with an example involving input foreclosure. ${ }^{29}$ Suppose that only two upstream suppliers compete to supply a critical input to several modestly-sized downstream firms. Suppose that these downstream firms compete with a larger downstream firm that also acquires inputs from these suppliers. The low input prices resulting from the upstream competition leads to greater downstream competition.

However, suppose next that one of the two upstream suppliers merges with the leading downstream firm. This merger inherently will reduce competition upstream and downstream. In the upstream market, the merged upstream supplier would gain the incentive to raise the price it charges for its input to the smaller buyers that it does not own. ${ }^{30}$ As a result of these input price increases, the smaller downstream firms 
There is no fundamental difference in incentives to

harm competition between horizontal and vertical

mergers that would justify a presumption that

vertical mergers in oligopoly markets are unlikely

to harm competition, but not a similar presumption

for horizontal ones.

would suffer higher costs. These higher costs in turn would induce the smaller downstream firms to compete less aggressively, reducing downstream competition overall. In particular, the smaller downstream firms would have an incentive to pass on their higher costs by raising their prices, which would permit the downstream merging firm to raise its price. In effect, the vertical merger would lead to involuntary pricing cooperation between the disadvantaged downstream firms and the downstream merging firm, leading to higher downstream prices. $^{31}$

It might be argued that this input foreclosure strategy would be unprofitable because the upstream merging firm would lose too many customers among the downstream rivals to the competing upstream supplier. It is the case that if the merged firm's upstream affiliate raises its prices, the downstream rivals it sells to would have an incentive to look for another supplier. However, as the only alternative input supplier, the competing input supplier normally would have an incentive to raise its own price in response, that is, to accommodate the price increase by the merged firm's upstream affiliate. ${ }^{32}$ It might not fully match the price increase, but it would be expected to accommodate it, at least partially. In conventional unilateral effects analysis, for example, a price increase by one differentiated products competitor typically leads the producers of differentiated substitutes also to raise their prices. Thus, the competing supplier would not be expected to prevent upstream prices from rising altogether. In addition, the incentive of the competing supplier to raise its prices would be exacerbated if some of the downstream firms are unwilling to purchase from the merged firm after the merger out of a fear that their confidential information will be shared with its downstream affiliate. ${ }^{33}$ These input price increases in turn make harm to the customers of the downstream firms more likely. If rivals' costs increase, downstream prices may increase from the downstream merging firm gaining power to raise prices.

The lesson of this example is that vertical mergers give the merged firm an inherent incentive to foreclose rivals at one vertical level (downstream in the example), at least when the market at the other vertical level (upstream in the example) has a structure that would give the competing input suppliers the incentive to at least partially accommodate the price increase by the merged firm. There is no fundamental difference in incentives to harm competition between horizontal and vertical mergers that would justify a presumption that vertical mergers in oligopoly markets are unlikely to harm competition, but not a similar presumption for horizontal ones. A horizontal merger among differentiated product firms in an oligopoly market has a normal tendency to raise prices. The same is true after a vertical merger in an oligopoly input market for a critical input, where the upstream merging firm is a substantial competitor. But, just as the inherent incentive after a vertical merger to increase the input price charged by the merged firm's upstream affiliate turns on market structure, so does the inherent incentive to raise price after a horizontal merger. ${ }^{34}$

Vertical mergers also raise coordinated effects concerns similar to those that can occur in horizontal mergers. Vertical mergers can eliminate sell-side mavericks or disruptive buyers. In addition, unlike strictly horizontal mergers, vertical mergers also can lead to anticompetitive information transfers from rivals to the merging firm. These information transfers can facilitate collusive information exchanges. ${ }^{35}$

The inherent exclusionary incentive created by vertical mergers combined with their ability to generate adverse coordinated effects means that enforcers should not presume that vertical mergers in oligopoly markets cannot harm competition. ${ }^{36}$ For the same reason, enforcers also should not set a higher evidentiary standard for finding anticompetitive harms from a vertical merger than it applies when reviewing horizontal deals.

2. EMPIRICAL EVIDENCE. As with economic theory, the empirical evidence does not justify presuming that vertical mergers in oligopoly markets benefit competition. Surveys of earlier economic studies, relied upon by commenters who propose a procompetitive presumption, reference studies of vertical mergers in which the researchers sometimes identified competitive harm and sometimes did not. ${ }^{37}$ However, recent empirical work using the most advanced empirical toolkit often finds evidence of anticompetitive effects. ${ }^{38}$ While vertical restraints, as distinct from vertical mergers, also can lead to efficiencies, they too can harm competition. ${ }^{39}$

It is inappropriate to base a presumption that vertical mergers are unlikely to harm competition on the examples collected in these earlier surveys. Some of the cited studies involve vertical integration (whether by explicit merger or contract) in competitive markets where a challenge would have been unlikely. Yet it is not possible to draw conclusions about the interbrand competitive effects of vertical mergers in oligopoly markets from studies of the consequences of a variety of vertical restraints and integration in competitive markets. Similarly, some studies involved the impact of divestitures required by state action for non-antitrust concerns, so they were less likely to show any impact of eliminating anticompetitive conduct. Other studies analyzed the impact of intrabrand restraints that might not have raised interbrand competition concerns. 
Moreover, some studies were not constructed to distinguish between cost-raising and elimination of double marginalization effects. For example, studies that compare the relative prices or shares of the downstream merging firm and its rivals, and stock market event studies that examine the impact of a merger on the stock price of a competitor of the merging firm, cannot distinguish between the effects of EDM and foreclosure..$^{40}$ The cited studies also disproportionately focus on a narrow set of industries (e.g., cable, beer), which may not be representative.

The surveyed studies also suffer from another selection bias. Studies of the competitive effects of vertical integration will be systematically biased in favor of finding procompetitive benefits when firms behave in the shadow of antitrust law. ${ }^{41}$ To isolate the overall competitive consequences of conduct, it is necessary to compare how that conduct affects competition with and without antitrust restraints, which the surveyed studies do not do. For example, in their study of resale price maintenance, MacKay and Smith avoid this selection bias by comparing outcomes in states with and without Leegin-repealer statutes. ${ }^{42}$

A concern about selection bias also can arise in studying the competitive impact of specific vertical mergers that were cleared by the agencies. Thus, the fraction of mergers that are found to be anticompetitive understates the rate of false negatives that would occur if enforcement were relaxed. Studies of the competitive effects of vertical integration are also systematically biased in favor of procompetitive benefits to the extent researchers depend on cooperation from the merging firms to obtain data.

Carefully Evaluate Merging Firms' Efficiency Claims. The other part of the argument that vertical merger enforcement should be very light-handed is a claim that vertical mergers are inherently efficient, even if markets are highly concentrated. ${ }^{43}$ Vertical mergers certainly can create efficiency benefits, just as horizontal mergers can. But such efficiencies are not necessarily merger-specific. Nor are they always sufficient to reverse the competitive harm. Moreover, a careful merger review should analyze whether these criteria are satisfied.

Claimed efficiencies must be substantiated so they can be verified, merger-specific, and not the product of an anticompetitive reduction in output or service. These cognizability criteria are just as important when analyzing claimed efficiencies from a vertical merger as they are for evaluating the claimed efficiencies from a horizontal merger - and they should be applied to evaluate those claims with equally close scrutiny. ${ }^{44}$ Efficiencies must also be sufficient to reverse any competitive harms. That is, pass-through of claimed efficiencies should be required in the analysis of vertical mergers to the same extent it is required in the analysis of horizontal mergers.

A careful analysis, rather than a presumption, also should be applied to efficiency claims involving the elimination of double marginalization. EDM often may occur from a ver- tical merger, but it is not an inevitable result. EDM already might have been achieved before the merger through bargaining that leads to multi-part tariffs, take-or-pay contracts, or other contractual provisions. A merger also will not generate EDM efficiencies if the downstream merging partner does not use the input produced by the upstream merging firm, for example because of incompatible technology. A recent study found that there are no inter-firm input transfers in almost half of the vertically integrated firms. ${ }^{45}$ In addition, EDM benefits may be limited because the integrated firm will take into account the fact that diversion of inputs from the merging firm's upstream affiliate to its downstream affiliate will sacrifice some profitable input sales by the upstream firm to downstream third parties that compete with the merged firm's downstream affiliate. ${ }^{46}$ This recognition limits the degree to which EDM leads the merging firm to lower its inter-firm input transfer prices or downstream prices. These possibilities make it essential that the magnitude of likely EDM be substantiated and verified.

Because EDM might be eliminated through negotiation of vertical contracts between independent firms, EDM should also be tested for merger-specificity; ${ }^{47}$ merger specificity should not simply be assumed without analysis. Even if the upstream firm sells its input to the downstream merging firm at a pre-merger price that exceeds marginal cost, that fact by itself does not prove that the efficiency is merger-specific. Even in the absence of formal two-part pricing schedules, contracts with quantity steps or minimums, or negotiations that explicitly or implicitly reward volume expansion, may substantially limit or completely eliminate double marginalization. For example, consider a patent license that sets a positive running royalty, but with a contractual purchase minimum that exceeds the likely purchases. In that situation, the effective marginal price is zero.

If in advance of the merger the parties never considered contracting to eliminate double marginalization, that fact may suggest that EDM would not achieve substantial benefits. If the parties tried and failed to negotiate a contract, it would be important to understand why the negotiation failed in order to determine whether the explanation is credible, as well as to determine whether double marginalization likely would be eliminated through a vertical merger. ${ }^{48}$ A general claim that there were "bargaining frictions" is an inadequate explanation, just as it would not be considered sufficient evidence of merger-specificity in horizontal merger cases. ${ }^{49}$ After all, the parties apparently were able to overcome bargaining frictions in successfully negotiating the merger agreement, and input prices are commonly negotiated between large firms. To mirror Robert Bork's famous remark about vertical restraints, ${ }^{50}$ if the parties' only reason for failing to achieve EDM is bargaining frictions, the Commission would do better by introducing the parties to a top-notch mediator or arbitrator rather than permitting an otherwise potentially anticompetitive merger. ${ }^{51}$ 


\section{Do Not Adopt a Safe Harbor Except Perhaps When Both Firms Compete in Unconcentrated Markets. The} agencies should decline to adopt a safe harbor for vertical mergers, except perhaps when both firms compete in unconcentrated markets. ${ }^{52}$ Vertical mergers involving firms in at least one oligopoly market raise the greatest competitive concerns. If both markets are unconcentrated, it is less likely that a vertical merger would be anticompetitive.

If even one of the markets is unconcentrated, however, a safe harbor would not be appropriate. For example, if the input market is concentrated, profitable input foreclosure does not require that the downstream market also be concentrated. Input foreclosure that raises the cost of all or most of the competitors in an unconcentrated downstream market could cause substantial diversion to the merged firm's downstream affiliate, making the input foreclosure profitable and leading to higher downstream prices. ${ }^{53}$ In addition, the coordinated effects from eliminating an upstream maverick would not require the downstream market to be concentrated, and concentration upstream would make it more likely that a maverick would constrain coordination in that market. Similarly, a disruptive buyer in an unconcentrated downstream market might constrain coordination in a concentrated upstream market - in which case its acquisition by an upstream firm could make coordination more effective.

Consider Adopting Anticompetitive Presumptions When Certain Conditions Are Met. The agencies should consider adopting rebuttable presumptions that a vertical merger harms competition when certain factual predicates are satisfied. We set out several possible presumptions here that could be invoked when at least one of the markets is concentrated, and thus, when competitive harm is more likely. ${ }^{54}$ In each case, the factual predicates aim to identify vertical mergers that are more likely to harm competition, so we would expect adoption of the presumption to enhance deterrence of anticompetitive conduct while reducing the costs of investigating and litigating vertical mergers and the costs associated with uncertainty about regulatory outcomes. By invoking a presumption, the plaintiff would satisfy its prima facie case, thereby shifting the burden of production to the merging firms.

We also emphasize that we do not intend these presumptions to describe all the ways by which vertical mergers can harm competition. These presumptions set out conditions where concerns are greatest. They identify narrow factual settings where competitive harm is particularly likely, and thus, where it is appropriate to presume anticompetitive harm. The agencies should continue to investigate vertical mergers that raise competitive concerns-including concerns about input and customer foreclosure, loss of a disruptive or maverick firm, or evasion of rate regulation - even if the specific factual predicates set forth in the following presumptions are not satisfied.

- Input foreclosure presumption: 55 If the upstream merging

firm in a concentrated market is a substantial supplier of a critical input to the competitors of the other merging firm and a hypothetical ${ }^{56}$ decision to stop dealing with those downstream competitors would lead to substantial diversion of business to the downstream merging firm. In this situation, a vertical merger can raise the costs of the unintegrated rivals and permit the merged firm to exercise market power in the downstream market. In this regard, it is important to emphasize that distributors provide an input (i.e., distribution services) to manufacturers, (as well as that manufacturers provide an input (i.e., the manufactured good) to distributors). ${ }^{57}$

- Customer foreclosure presumption: ${ }^{58}$ If the downstream merging firm is a substantial purchaser of the input produced in a concentrated upstream market, and a decision to stop dealing with the competitors of the upstream merging firms would lead to the exit, marginalization, or significantly higher variable costs of one or more of those competitors by diverting a substantial amount of business away from them. In this situation, a vertical merger can reduce competition in the upstream market and permit the merged firm to exercise market power. ${ }^{59}$

- Elimination of potential entry presumption: If either (or both) of the merging firms has a substantial probability of entering into the other firm's concentrated market absent the merger. In this situation, the merger would eliminate the possibility that entry (or the fear of that entry if the incumbent firm charges excessive prices) would make the market more competitive.

- Disruptive or maverick seller presumption: If the upstream merging firm in a concentrated input market supplies the product purchased by competitors of the other merging firm, and by its conduct has prevented or substantially constrained coordination in the upstream market. In this situation, the constraining influence of the disruptive or maverick firm could be eliminated, leading to higher market prices.

- Disruptive or maverick buyer presumption: If the downstream merging firm purchases the product sold by the other merging firm or its competitors, and by its conduct has prevented or substantially constrained coordination in the sale of that product by the other merging firm and its competitors in a concentrated input market. In this situation, the constraining influence of the disruptive or maverick firm could be eliminated, leading to higher market prices.

- Evasion of regulation presumption: If the downstream firm's maximum price is regulated, competition nonetheless may be harmed from a vertical merger. This can occur, for example, if the regulation permits the downstream firm to raise its price in response to cost increases. The regulated downstream firm could raise the price of the input supplied to it by its upstream merger partner, increasing upstream profits and downstream prices. Evasion of regulation could also occur if the merger involves firms that sell complementary products. The newly merged firm 
could raise the price of the bundle and attribute the price increase to the unregulated product.

- Dominant platform presumption: If a dominant platform acquires a firm with a substantial probability of entering in competition with it absent the merger, or if that dominant platform company acquires a competitor in an adjacent market. Rivals in vertically adjacent or complementary markets are often potential entrants, so this presumption reaches nascent threats to competition created by eliminating the potential entrants through the merger. The presumption also recognizes that a dominant platform's market power would give it the ability to substantially disadvantage firms in adjacent markets by choosing not to interoperate, which can raise foreclosure concerns. This presumption can be understood as an application of the elimination of potential entry presumption and an input or customer foreclosure presumption in a setting where network effects and economies of scale would be expected to raise barriers to entry, and thus endow a dominant platform with substantial market power.

None of these presumptions is purely structural in the sense of being based solely on market shares and concentration. The dominant platform presumption that would apply to a vertical merger if at least one of the merging firms is a dominant platform would be the closest.

All of these anticompetitive presumptions would be rebuttable, so they would not create per se prohibitions of vertical mergers. If the agencies adopt any or all of the presumptions, they should allow them to be rebutted by evidence showing that anticompetitive effects are unlikely. In the case of the input foreclosure presumption, for example, this could include evidence that the input was not critical, that substantial input market competition (including entry competition) would protect the targeted downstream rivals from cost increases, that sufficient downstream competition by non-targeted firms would prevent downstream price increases and consumer harm, that the expected margin and diver- sion ratio to the downstream merging firm would be very low, that sufficient countervailing buyer power would prevent upstream price increases, and so on. As should be evident, the type of evidence that could rebut the inference of anticompetitive effect would depend on the competitive effects theory that underlies the presumption.

\section{Conclusion}

The widely divergent views about enforcement policy that we noted in our introduction may make it hard for practitioners to counsel clients about vertical mergers or advocate before the agencies, whether they are supporting or questioning the transaction. Our analysis can be particularly useful for those advocates who may have wrongly supposed that vertical mergers should or will be presumed to benefit competition. As we have explained, modern economic analysis does not support a relaxed approach to vertical merger review and enforcement. For that reason, advocates should address the full range of potential competitive harms, with reference to the specific facts of their transaction, and apply the rigorous mainstream modern economic thinking that we have relied upon. For the same reason, advocates should analyze carefully the magnitude of claimed efficiencies, their mergerspecificity, and the likelihood that they would reverse the potential anticompetitive effect.

We are also writing for the enforcement agencies, by setting forth our views on critical issues regarding vertical merger enforcement policy that the Commission must address in any hearings report and the agencies must resolve in formulating revised vertical merger guidelines. We have recommended these five principles to anchor effective vertical merger enforcement by reducing false negatives while keeping false positives low. We hope that the agencies will agree and follow our recommendations even before they release new vertical merger guidelines. These recommendations also could be useful if the Congress decides to amend Section 7 of the Clayton Act.
1 U.S. Dep't of Justice, Non-Horizontal Merger Guidelines (1984), https:// www.justice.gov/sites/default/files/atr/legacy/2006/05/18/2614.pdf.

2 See, e.g., D. Bruce Hoffman, Acting Director, Bureau of Competition, Fed. Trade Comm'n, Vertical Merger Enforcement at the FTC 4 n.9 (Jan. 10, 2018), http://www.ftc.gov/system/files/documents/public_statements/ 1304213/hoffman_vertical_merger_speech_final.pdf.

3 The importance of rigorous economic analysis is a different question from whether antitrust should recognize non-economic goals, such as preventing threats to the political process from corporate giants or protecting access to the market by small business, along with economic ones, such as the familiar concern to protect consumer (trading partner) welfare.

4 Staples, Inc., FTC No. 181-0180 (Jan. 28, 2019) (Statement of Chairman Joseph J. Simons, Comm'r Noah Joshua Phillips, and Comm'r Christine S. Wilson) [hereinafter Staples Majority Statement]; Staples, Inc., FTC No. 181-0180 (Jan. 28, 2019) (Statement of Comm'r Christine S. Wilson) [hereinafter Commissioner Wilson Staples Statement]; Staples, Inc., FTC No.
181-0180 (Jan. 28, 2019) (Dissenting Statement of Comm'r Rebecca Kelly Slaughter) [hereinafter Commissioner Slaughter Staples Statement]; Staples, Inc., FTC No. 181-0180 (Jan. 28, 2019) (Dissenting Statement of Comm'r Rohit Chopra) [hereinafter Commissioner Chopra Staples Statement].

5 Fresenius Medical Care AG, FTC No. 171-0227 (Feb. 19, 2019) (Decision and Order). Fresenius Medical Care AG, FTC No. 171-0227 (Feb. 19, 2019) (Statement of Chairman Joseph J. Simons, Comm'r Noah Joshua Phillips, and Comm'r Christine S. Wilson) [hereinafter Fresenius Majority Statement]; Fresenius Medical Care AG, FTC No. 171-0227 (Feb. 19, 2019) (Dissenting Statement of Comm'r Slaughter) [hereinafter Fresenius Slaughter Statement]; Fresenius Medical Care AG, FTC No. 171-0227 (Feb. 19, 2019) (Dissenting Statement of Comm'r Chopra) [hereinafter Fresenius Chopra Statement].

6 Christine S. Wilson, Comm'r, Fed. Trade Comm'n, Vertical Merger Policy: What Do We Know and Where Do We Go? Keynote Address at the GCR Live 8th Annual Antitrust Law Leaders Forum (Feb. 1, 2019), https://www. 
ftc.gov/system/files/documents/public_statements/1455670/wilson__vertical_merger_speech_at_gcr_2-1-19.pdf.

7 Two of the authors (Baker and Scott Morton) joined Brief for 27 Antitrust Scholars as Amici Curiae in Support of Neither Party, United States v. AT\&T, No. 18-5214 (D.C. Cir. filed Aug. 13, 2018) (No. 18-5214) [hereinafter 27 Scholars]; Corrected Proof Brief of Amici Professor William P. Rogerson and American Cable Association in Support of Appellant, United States v. AT\&T, No. 18-5214 (D.C. Cir. filed Aug. 21, 2018); Brief Amici Curiae of 37 Economists, Antitrust Scholars, and Former Government Antitrust Officials in Support of Appellees and Supporting Affirmance, United States v. AT\&T, No. 18-5214 (D.C. Cir. filed Sept. 26, 2018).

8 Makan Delrahim, Assistant Att'y Gen., Antitrust Div., U.S. Dep't of Justice, Harder Better Faster Stronger: Evaluating EDM as a Defense in Vertical Mergers, Remarks at George Mason Law Review 22nd Annual Antitrust Symposium (Feb. 15, 2019), https://www.justice.gov/opa/speech/assis tant-attorney-general-makan-delrahim-delivers-remarks-george-mason-lawreview-22nd.

9 One of the authors (Salop) made the lead presentation at the FTC Vertical Merger Hearing (Nov. 1, 2019). See Steven C. Salop, Revising Vertical Merger Guidelines, Hearing \#5 on Competition and Consumer Protection in the 21st Century (Nov. 1, 2018), https://www.ftc.gov/system/files/docu ments/public_events/1415284/ftc_hearings_5_georgetown_slides.pdf. Presentations with differing views were made by other participants. Id. Diverse opinions also were expressed by the participants at two panels. For the unedited transcript, see Fed. Trade Comm'n, Competition and Consumer Protection in the 21st Century (Nov. 1, 2018) [hereinafter FTC Hearing Transcript], https://www.ftc.gov/system/files/documents/public_events/ 1415284/ftc_hearings_session_5_transcript_11-1-18.pdf.

10 United States v. AT\&T, Inc., No. 18-5214, 2019 WL 921544 (D.C. Cir. Feb. $26,2019)$.

$11 / d$. at $* 1$. The court declined to opine further on the proper legal standards for evaluating vertical mergers on the ground that doing so was unnecessary to decide the case. $I d$. at $* 5$. With respect to merger law generally, the court "[did] not hold that quantitative evidence of price increase is required in order to prevail on a Section 7 challenge." $I$. at $* 13$.

12 Id. at *1-2; United States v. Baker Hughes Inc., 908 F.2d 981, 982-83 (D.C. Cir. 1990); FTC v. H.J. Heinz Co., 246 F.3d 708, 715 (D.C. Cir. 2001); United States v. Phila. Nat'l Bank, 374 U.S. 321, 363 (1963).

13 Steven C. Salop, Invigorating Vertical Merger Enforcement, 127 YALE L.J. 1962 (2018); Steven C. Salop \& Daniel P. Culley, Revising the U.S. Vertical Merger Guidelines: Policy Issues and an Interim Guide for Practitioners, 4 J. Antitrust Enforcement 1 (2016).

${ }^{14}$ For example, the DOJ concerns regarding the Google/ITA and LAM/KLA mergers focused on innovation harms. See Jon Sallet, Deputy Assistant Att'y Gen., Antitrust Div., U.S. Dep't of Justice, The Interesting Case of Vertical Merger, Remarks at the Am. Bar Ass'n Fall Forum (Nov. 17, 2016), https:// www.justice.gov/opa/speech/deputy-assistant-attorney-general-jon-salletantitrust-division-delivers-remarks-american.

15 See, e.g., Steven C. Salop, Invigorating Vertical Merger Enforcement, 127 YALE L.J. 1962 (2018); Thomas G. Krattenmaker \& Steven C. Salop, Anticompetitive Exclusion: Raising Rivals' Costs to Achieve Power over Price, 96 YALE L.J. 209 (1986); Michael H. Riordan \& Steven C. Salop, Evaluating Vertical Mergers: A Post-Chicago Approach, 63 ANTITRust L.J. 513 (1995); Jonathan Baker, Exclusion as a Core Competition Concern, 78 ANTITRUSt L.J. 527, 538-43 (2013); Eric B. Rasmusen et al., Naked Exclusion, 81 Ам. Econ. Rev. 1137, 1140-43 (1991) (explaining how competition can be harmed through exclusionary vertical agreements); Patrick Rey \& Jean Tirole, A Primer on Foreclosure, in 3 HandBook of Industrial Organization 2145 (Mark Armstrong \& Robert H. Porter eds., 2007) (surveying theories); Oliver Hart \& Jean Tirole, Vertical Integration and Market Foreclosure, 21 Brookings Papers on Economic Activity (Microeconomics) 205 (1990).

16 See, e.g., studies cited infra note 38.

17 See, e.g., the list of agency consents in Steven C. Salop \& Daniel P. Culley, Vertical Merger Enforcement Actions: 1994-July 2018, GEO. U.L. CTR. (Aug. 23, 2018), https://scholarship.law.georgetown.edu/cgi/viewcontent.cgi? article $=2541 \&$ context=facpub. These figures update the earlier enforcement statistics cited in Salop \& Culley, supra note 13.
18 For further discussion of this modern concept of foreclosure, see, e.g., Steven C. Salop, The Raising Rivals' Cost Foreclosure Paradigm, Conditional Pricing Practices, and the Flawed Incremental Price-Cost Test, 81 Antitrust L.J. 371, 382-95 (2017).

19 Id.; Continental T.V., Inc. v. Sylvania Inc., 433 U.S. 36, 57 n.24 (1977) (stating that distributors charge a "cost of distribution").

20 Anticompetitive conduct in markets where buyers and sellers determine terms of trade through negotiation does not necessarily require a short-run reduction in output. C. Scott Hemphill \& Nancy L. Rose, Monopsony, Bargaining Leverage, and Buy-Side Benefits in Mergers, 127 YALE L.J. 2078 (2018).

21 For some formal economic models of the impact of vertical mergers on coordination, see, e.g., Volker Nocke \& Lucy White, Do Vertical Mergers Facilitate Upstream Collusion?, 97 Am. Econ. Rev. 1321 (2007); Volker Nocke \& Lucy White, Vertical Merger, Collusion, and Disruptive Buyers, 28 INT'L J. INDUS. ORG. 350 (2010); Hans-Theo Normann, Vertical Integration, Raising Rivals' Costs and Upstream Collusion, 53 Eur. Econ. Rev. 461 (2009).

22 See United States v. AT\&T, Inc., No. 18-5214, 2019 WL 921544, at*13 (D.C. Cir. Feb. 26, 2019).

23 See, e.g., Oliver E. Williamson, The Vertical Integration of Production: Market Failure Considerations, 61 Am. Econ. Rev. 112 (1971); Paul L. Joskow, Vertical Integration, in HANDBOOK of NeW Institutional ECONOMICS 319 (Claude Menard \& Mary M. Shirley eds., 2005); Martin K. Perry, Vertical Integration: Determinants and Effects, in 1 HANDBOOK OF INDUSTRIAL ORganization 183 (Richard Schmalensee \& Robert Willig eds., 1989); Francine Lafontaine \& Margaret Slade, Vertical Integration and Firm Boundaries: The Evidence, 45 J. Econ. LITERATURE 629 (2007); Michael H. Riordan, Competitive Effects of Vertical Integration, in HANDBOOK OF ANTITRUST Economics 145 (Paolo Buccirossi ed., 2008)

${ }^{24}$ For the seminal analysis of EDM, see Joseph J. Spengler, Vertical Integration and Antitrust Policy, 58 J. PoL. ECon. 347 (1950).

25 Daniel O'Brien, FTC Hearing, supra note 9, at 40 (logic calls for rebuttable presumption of benefits in concentrated markets); LaFontaine \& Slade, supra note 23 , at 71 (more positive view of vertical mergers as a starting point). Similar arguments are made with respect to vertical restraints. See, e.g., James C. Cooper et. al, Vertical Antitrust Policy as a Problem of Inference, 23 INT'L J. INDUS. ORG. 639 (2005). Yet the Supreme Court has not mandated per se legality or adopted an overarching procompetitive presumption in reviewing vertical restraints under the Sherman Act, but instead has applied the conventional rule of reason. Leegin Creative Leather Prods., Inc. v. PSKS, Inc., 551 U.S. 877, 894-99 (2007). Competitive effects analysis under Section 7 should be no more hospitable to defendants, as the Clayton Act authorizes the prevention of competitive harms in their incipiency. Consistent with this analysis, the D.C. Circuit in AT\&T declined to presume that vertical mergers benefit competition. AT\&T, WL 921544, at $* 1$.

${ }^{26}$ E.g., Hoffman, supra note 2, at 2-3; Carl Shapiro, FTC Hearing, supra note 9 , at 58 (horizontal mergers have a direct loss of competition unlike vertical mergers). The other part of the argument involves the claim that the vertical mergers inherently create efficiency benefits, as discussed infra.

27 Robert H. Bork, The Antitrust Paradox: A Policy at War With Itself 232 (1978). See Fruehauf Corp. v. FTC, 603 F.2d 345, 352 n.9 (2d Cir. 1979) (“[A] vertical merger may simply realign sales patterns.").

2827 Scholars, supra note 7 , at 7-8.

29 This incentive also could be illustrated for customer foreclosure by the downstream affiliate of the merged firm. In this comment, we use the terms upstream and downstream for expositional convenience; as a matter of economics, the merger of firms selling demand complements should be considered a vertical merger regardless of whether it is intuitive to view one as downstream of another in a supply chain. All of the theories and presumptions we discuss would apply in such cases as well.

30 Before the merger, the upstream merging firm would have raised its wholesale price to the point where the gains from charging more were just offset by the lost contribution to profit from the reduction in downstream sales. But that calculus would change as a result of the merger. Now, a higher input price causes diversion of some downstream sales to the merged firm's 
downstream affiliate from the rival downstream firms when the cost increases lead the latter firms to raise their prices.

31 See Jonathan B. Baker, Exclusion as a Core Competition Concern, 78 ANTITRUST L.J. 527, 556-58 (2013) (explaining that exclusionary conduct can harm competition by creating an involuntary or coerced cartel).

32 This is what Krattenmaker \& Salop term the "Frankenstein monster" scenario. Krattenmaker \& Salop, supra note 15, at 241-42.

33 In her statement on the Staples/Essendant merger, Commissioner Slaughter made a similar point. Commissioner Slaughter Staples Statement, supra note 4 , at 8 .

34 For example, price would not normally rise after a horizontal merger when non-merging rivals have constant marginal costs and act as price-takers in an unconcentrated market. In that case, the rivals would not be expected to accommodate a post-merger price increase by the merged firm.

35 Information exchanges also can have exclusionary effects by allowing the merging firm to preempt or more quickly match rivals' innovations. That conduct could deter innovation.

36 See Jonathan B. Baker, The Antitrust Paradigm 141-42 (2019).

37 James C. Cooper et al., Vertical Antitrust Policy as a Problem of Inference, 23 INT'L J. INDUS. ORG. 639 (2005); Francine Lafontaine \& Margaret Slade, Exclusive Contracts and Vertical Restraints: Empirical Evidence and Public Policy, in Handbook of AntiRust Economics 391 (Paolo Buccirossi ed., 2008). At the FTC Hearing, Margaret Slade observed that the results of the studies of vertical mergers were mixed and the set of industries studied was narrow. See FTC Hearing Transcript, supra note 9, at 51 (The transcript records the word "fixed" when the speaker actually said "mixed.").

38 Examples in the last decade include Fernando Luco \& Guillermo Marshall, Vertical Integration with Multiproduct Firms: When Eliminating Double Marginalization May Hurt Consumers (Working Paper, Jan. 15, 2018), https://ssrn.com/abstract=3110038; Laurence C. Baker et al., Does Multispecialty Practice Enhance Physician Market Power? (Nat'l Bureau of Econ. Research. Working Paper No. 23871, 2017), http://www.nber.org/ papers/w23871; Leemore Dafny et al., The Price Effects of Cross-Market Hospital Mergers (Nat'l Bureau of Econ. Research. Working Paper No. 22106, 2018) (addressing mergers involving demand complements); JeanFrançois Houde, Spatial Differentiation and Vertical Mergers in Retail Markets for Gasoline, 102 Am. Econ. Rev. 47 (2012); Gregory S. Crawford et al., The Welfare Effects of Vertical Integration in Multichannel Television Markets 86 ECONOMETRICA 891 (2018) (evidence that vertical integration of cable TV distributors with regional sports networks sometimes raised prices, even using lower bound estimates of harm); Johannes Boehm \& Jan Sonntag, Vertical Integration and Foreclosure: Evidence from Production Network Data (Sciences Po Econ. Discussion Paper No. 2018-12, 2018), https:// jmboehm.github.io/foreclosure.pdf (suppliers more likely to break relationships with buyers when they integrate with competitor of buyers, relative to integration with non-competitor).

39 See Margaret C. Levenstein \& Valerie Y. Suslow, How Do Cartels Use Vertical Restraints? Reflections on Bork's The Antitrust Paradox, 57 J.L. \& EcoN. S33, S42 (2014) (concluding that at least one-quarter of cartels used ver tical restraints to support their exercise of market power); see generally Jonathan B. Baker, Taking the Error out of "Error Cost" Analysis: What's Wrong with Antitrust's Right, 80 ANTITRUSt L.J. 1, 17-23 (2015).

40 Stock market event studies also are unable to control for the impact on stock prices of investors' expectations that competitors will be acquired in subsequent mergers, among other problems. Studies that assume that the contracts between the upstream and downstream firms take simple forms may build in double marginalization, and then identify an EDM benefit from merger by virtue of that assumption, without evaluating whether it actually occurred.

41 Baker, supra note 39, at 19-22.

42 Alexander MacKay \& David Smith, The Empirical Effects of Minimum Resale Price Maintenance on Prices and Output (Working Paper, Aug. 28, 2016) (finding that resale price maintenance typically harmed competition for the products studied), https://ssrn.com/abstract=2513533.

43 Daniel O'Brien, FTC Hearing Transcript, supra note 9, at 40 (mergers among complements in concentrated markets create downward pricing pressure, implying presumptive benefits); Francine Lafontaine, FTC Hearing Transcript, supra note 9 , at 71 (interests of sellers of complements aligned with consumers); Hoffman, supra note 2 at 143 (EDM is an inherent effect).

44 A verifiability requirement is necessary to prevent overreaching claims not supported by sufficient evidence. A merger-specificity requirement is necessary because, as explained by Ronald Coase in his seminal article, vertical contracts can substitute for vertical mergers in some circumstances. Ronald H. Coase, The Nature of the Firm, 16 Economica 386 (1937); Sanford J. Grossman \& Oliver Hart, The Costs and Benefits of Ownership: A Theory of Vertical and Lateral Integration, 94 J. PoL. Econ. 691 (1986).

45 Enghin Atalay, Ali Hortaçsu \& Chad Syverson, Vertical Integration and Input Flows, 104 Am. Econ. REv. 1120, 1127 (2014) (finding that almost half of establishments report no internal shipments). This point was noted at the FTC Hearing by Margaret Slade. FTC Hearing Transcript, supra note 9, at 49.

46 Serge Moresi \& Steven C. Salop, vGUPPI: Scoring Unilateral Pricing Incentives in Vertical Mergers, 79 ANTITRUst L.J. 185 (2013).

4727 Scholars, supra note 7 , at 15. See also Coase, supra note 44 .

48 Improved allocation of downstream demand risk might be claimed as a reason why it would be difficult to negotiate a two-part tariff. However, in the case of two large firms, a two-part tariff that places the demand risk on the downstream firm is unlikely to be sufficiently inefficient to justify an otherwise problematic vertical merger.

49 In reviewing a horizontal merger, for example, we doubt that the agencies would consider merger-specific a claim that the merger would eliminate a patent royalty or would allow the firms to settle their ongoing patent infringement litigation by eliminating bargaining frictions.

50 Bork, supra note 27.

51 In an analogous bargaining setting, most lawsuits settle. It is very rare for large firms involved in a lawsuit to settle the suit by merging.

52 Safe harbors normally are rebuttable in extreme circumstances, for example, where documents indicate significant anticompetitive concern.

53 To illustrate, suppose that the upstream input market is a duopoly and the downstream output market is unconcentrated and comprised of ten firms, each with a market share of $10 \%$. If the vertical merger leads both upstream firms to raise prices significantly to the nine unintegrated competitors, their resulting cost increases could cause them to raise downstream prices, creating substantial customer diversion to the downstream affiliate of the merged firm and providing that affiliate with the power and incentive to raise its price (rather than simply increase its market share). This is also an example of the involuntary cooperation discussed in Baker, supra note 31, at 556-58.

54 We do not propose a particular level of concentration at which to apply these presumptions. However, we would discourage the agencies from relying on the threshold for a "highly concentrated" market employed in the 2010 Horizontal Merger Guidelines, as we are concerned that this threshold was set at an overly permissive level. U.S. Dep't of Justice \& Fed. Trade Comm'n, Horizontal Merger Guidelines 19 (2010) (HHI of 2500 as threshold for a highly concentrated market).

55 Although the factual predicate for application of this presumption incorporates a conceptual experiment involving complete foreclosure of the critical input, the competitive harm could instead arise from higher input prices or other exclusionary conduct short of full foreclosure.

56 There are numerous other (and generally more profitable) foreclosure strategies. However, for purposes of the presumption, we are using this more extreme strategy. A stronger presumption would contemplate a small but significant input price increase.

57 After the merger, the distributor may foreclose rival manufacturers by rais ing the price of its services or refusing to provide its services. See Salop, supra note 18 , at 384 .

58 Although the factual predicate for application of this presumption incorporates a conceptual experiment involving complete foreclosure of the upstream firm access to the market, the competitive harm could instead arise from exclusionary conduct short of full foreclosure.

59 If the upstream merging firm sells to the competitors of the downstream firm, customer foreclosure can lead to input foreclosure. For further details, see Salop, supra note 18 , at 389. 